\title{
THE EFFECT OF STRAIN RATE ON THE PROPERTIES AND MICROSTRUCTURE OF THE DC 06 STEEL
}

\author{
VLIV RYCHLOSTI DEFORMACE NA VLASTNOSTI A STRUKTURU OCELI DC 06
}

\begin{abstract}
The effect of strain rate on the process of flat forming at room temperature has not been clearly defined yet. So far, the effect of strain rate has only been assessed for hot forming technology. The current industry specialising in flat forming technology place great emphasis on the reduction of material consumption and the number of rejected pressed parts, on the increase of productivity and quality of work, use of advanced pressing machines (e.g. servo presses), etc. All the aforesaid make us ask how to modify the boundary conditions of the pressing process in order to meet the requirements. It shows that standard conditions influencing the pressing process, e.g. pressure generated by the holder, lubrication, application of draw beat, are not able to influence the process to the full extent and it is necessary to seek potential in other boundary conditions. It becomes more and more obvious that strain rate has a major impact on the pressing process. This article aims to describe the influence of strain rate on the formability in flat forming technology and on the behaviour of microstructure after deformation in various material lots of the DC06 steel.
\end{abstract}

\begin{abstract}
Abstrakt
Vliv rychlosti deformace na proces plochého tváření, při pokojové teplotě nebyla dosud jasně definována. Dosud byl vliv rychlosti deformace posouzen pouze technologií tváření za tepla. Současný průmysl se specializuje na technologie plochého tváření a klade velký důraz na snížení spotřeby materiálu a počtu odmítnutých lisovaných dílů, na zvýšení produktivity a kvality práce, využívání moderních lisůh (např. servo lisy), atd. Uvedené nás nutí zeptat se, jak změnit okrajové podmínky procesu lisování za účelem splnění požadavků. Ukazuje se, že standardní podmínky ovlivňující lisování, např. tlak od držáku, mazání, použití úderů, nejsou schopny ovlivnit proces $\mathrm{v}$ plném rozsahu, a že je třeba hledat potenciál $\mathrm{v}$ dalších okrajových podmínkách. Je více a více zřejmé, že rychlost deformace má významný vliv na lisování. Tento článek si klade za cíl popsat vliv rychlosti deformace na tvařitelnost $\mathrm{v}$ technologie plochého tváření a na chování mikrostruktury po deformaci v různých materiálových variantách oceli DC06.
\end{abstract}

\section{INTRODUCTION}

In general, the effect of strain rate on the process of flat forming at room temperature has not been taken into account for being rather underestimated. However, modern trends in the area of pressing, mainly the constant emphasis on the growth of production and related increase in the number of pressing line cycles suggest that it is necessary to start taking this parameter into consideration.

Relevant literature [1] suggests that the higher strain rate, the higher deformation resistance, ultimate tensile strength, yield point and the lower ductility of material. This increase in the mechanical values can be generally found in tough materials and is the more obvious the lower the melting

\footnotetext{
${ }^{1}$ F. TATICEK, T. PILVOUSEK, T. PACAK, L. TURZA, CTU in Prague, Faculty of Mechanical Engineering,
} Department of Manufacturing technology, Czech Republic 
temperature of the relevant metal. An extreme increase in the value of the strain rate can result in even malleable materials failing by brittle fracture.

The higher strain rate the higher density of lattice defects, deformation resistance and metal energy level. Also dislocations move at higher speed.

Assuming that the strain strength of material is influenced by the amount of deformation as well as the strain rate, we can use the following power law [1]:

$$
k_{p}=C \cdot \varphi^{n} \cdot \dot{\varphi}^{m}
$$

Table 1. Explanation of symbols found in the power law

\begin{tabular}{|c|l|c|}
\hline Symbols in the equation & \multicolumn{1}{|c|}{ Explanation of symbols } & Units \\
\hline $\boldsymbol{k}_{\boldsymbol{p}}$ & Deformation resistance & {$\left[\mathrm{N} \cdot \mathrm{mm}^{-2}\right]$} \\
\hline $\boldsymbol{C}$ & Deformation strength for $\boldsymbol{\varphi}=1 \mathrm{a \dot { \varphi } = 1}$ & \\
\hline $\boldsymbol{\varphi}$ & True strain & {$[-]$} \\
\hline$\dot{\varphi}$ & Strain rate & {$\left[\mathrm{s}^{-1}\right]$} \\
\hline $\boldsymbol{n}$ & Strain hardening exponent & {$[-]$} \\
\hline $\boldsymbol{m}$ & Coefficient of strain rate sensibility & {$[-]$} \\
\hline
\end{tabular}

Technical literature specifies [2] for malleable metal materials and cold flat forming technology the value of strain hardening exponent to be 0.25 and the value of the exponent indicating the influence of stress sensitivity on the strain to be 0 , which is in accordance with the general presumption that strain rate does not influence the cold flat forming process.

Naturally, there are a number of other models, e.g. the additive model published in technical literature [2] specifying the effects of the amount of deformation and strain rate on material mechanical properties.

The models which take account of the effects of strain rate are being developed even in the numerical simulations of the pressing process. One of such models is the Corrus Vegter material model, which takes account of material sensitivity to strain rate.

\subsection{Strain rate definition:}

Strain rate $\dot{\varphi}$ is the rate of change in strain $\mathrm{d} \varphi$ with respect to time $\mathrm{dt}$ [1]:

$$
\dot{\varphi}=\frac{d \varphi}{d t}
$$
nal length:

The change in strain can be specified as a ratio of the length under applied stress to the origi-

$$
d \varphi=\frac{d l}{l_{0}}
$$

Strain rate in real technological processes is a variable, thus it does not equal the speed of tool movement. For example, the following applies to the tension test [1]:

$$
\dot{\varphi}=\frac{v}{l}
$$


Where $v$ is the speed of tool movement and $l$ is the length of the path travelled so far. The relation (4) can be derived from the fact that real deformation $\varphi$ :

$$
\varphi=\ln \frac{l_{0}}{l_{1}}
$$

Substituting the relation of (5) into the relation of (2) results in the following equation:

$$
\dot{\varphi}=\frac{d\left(\ln \frac{l_{0}}{l_{1}}\right)}{d t},
$$

Which implies that:

$$
\dot{\varphi}=\frac{1}{l_{1}} \cdot \frac{d l_{1}}{d t},
$$

The speed of tool movement can be expressed as the ratio of the change in length to the change in time:

$$
v=\frac{d l_{1}}{d t}
$$

By substituting the relation of (8) into the relation of (7) we obtain the relation between the strain rate and the speed of the movement of the cross bar (4).

\section{DESCRIPTION OF MATERIAL}

The material and mechanical properties of the DC06 steel has been specified in the standard EN 10152 (Electrolytically zinc coated cold rolled steel flat products for cold forming - Technical delivery conditions). It is alloy, high-grade, low-carbon, ferritic steel micro-alloyed with titanium (the standard requires the maximum amount of 0.3 mass \%), which serves as a carbonitride stabilizer cleaning the ferrite from interstitially dissolved carbon and nitrogen. By reducing the presence of these elements, it increases the value of normal anisotropy and improves the deep-drawing properties. Titanium, carbon and nitrogen mix to form TiCN which can be seen under a microscope as yellow sharp-edge inclusions in the material, see Fig.1.

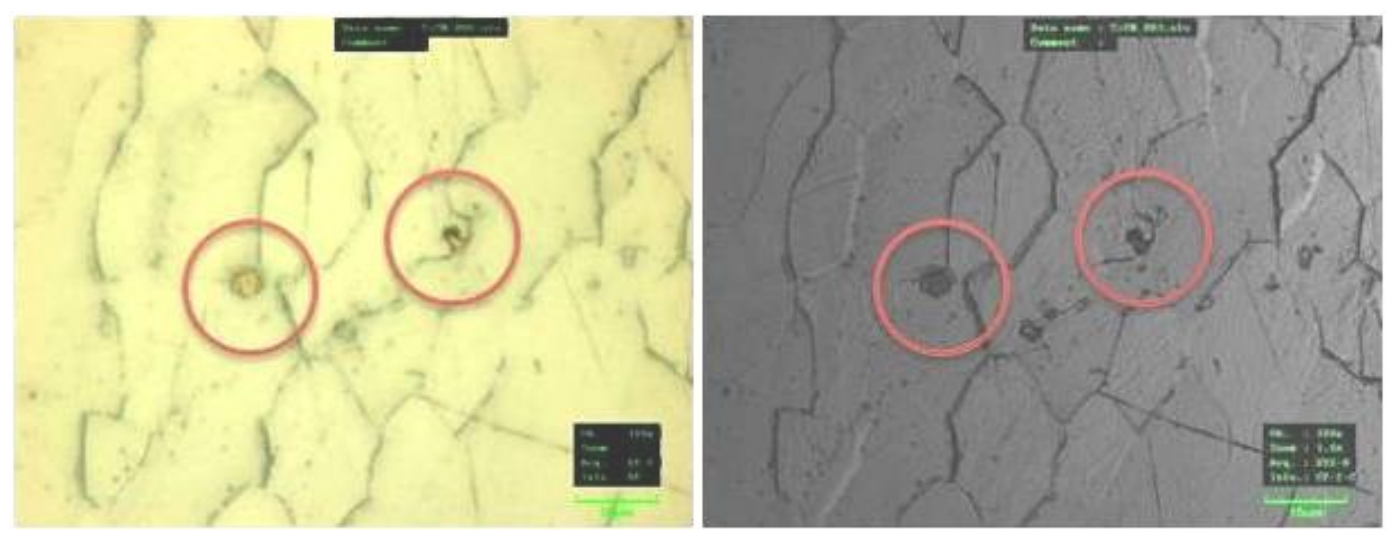

Fig. 1. DC06 ZE50/50 BPO with visible inclusions of TiCN; to the left in a 2D image, to the right as black spots in a $3 \mathrm{D}$ image. The images have been magnified 2400 times.

The material is produced as fully killed. The stability (killing) of the steel is ensured by aluminium. 
The nominal thickness of the metal sheet we have analysed is $0.75 \mathrm{~mm}$. Resistance to corrosion is ensured by an electrolytically deposited layer of zinc $(5 \mu \mathrm{m})$. The metal sheet features EDT (electric discharge texturing) ensured by a layer of phosphate.

The basic material information specified in the standard EN 10152 is summarized in the following tables [3]:

Table 2. Chemical composition of DC06 ZE50/50 BPO

\begin{tabular}{|c|c|c|c|c|}
\hline \multicolumn{5}{|c|}{ Chemical composition of DC06 ZE50/50 BPO } \\
\hline \multicolumn{5}{|c|}{ The values show the maximum weight proportion [\%] } \\
\hline $\mathrm{C}$ & $\mathrm{P}$ & $\mathrm{S}$ & $\mathrm{Mn}$ & $\mathrm{Ti}$ \\
\hline 0.020 & 0.020 & 0.020 & 0.250 & 0.30 \\
\hline
\end{tabular}

Table 3. Mechanical properties of DC06 ZE50/50 BPO

Mechanical properties of DC06 ZE50/50 BPO

\begin{tabular}{|c|c|c|c|c|}
\hline$R_{\mathrm{e}}\left[\mathrm{N} \cdot \mathrm{mm}^{-2}\right]$ & $R_{\mathrm{m}}\left[\mathrm{N} \cdot \mathrm{mm}^{-2}\right]$ & $A_{80}[\%]$ & $\mathrm{r}_{90}[-]$ & $\mathrm{n}_{90}[-]$ \\
\hline$\div 180$ & $270 \div 350$ & min. 41 & min. 2.1 & min. 0.21 \\
\hline
\end{tabular}

\section{TESTING METHOD}

Mechanical properties of the material were determined using the Labtest 5.100SP1 testing device and the Test\&Motion evaluation software. Samples were always taken in three directions $\left(0^{\circ}\right.$, $45^{\circ}, 90^{\circ}$ ) with respect to the direction of rolling.

In order to describe the influence of strain rate on basic mechanical properties, the situation was simplified by choosing seven constant speeds of the cross bar in consideration of the possibilities of the used machine. The chosen speeds of cross bar were $10 \mathrm{~mm} \cdot \mathrm{min}^{-1}, 15 \mathrm{~mm} \cdot \mathrm{min}^{-1}, 30 \mathrm{~mm} \cdot \mathrm{min}^{-1}$, $50 \mathrm{~mm} \cdot \mathrm{min}^{-1}, 100 \mathrm{~mm} \cdot \mathrm{min}^{-1}, 200 \mathrm{~mm} \cdot \mathrm{min}^{-1}$ and $500 \mathrm{~mm} \cdot \mathrm{min}^{-1}$. Tree samples were tested for each parameter and the arithmetic mean of these three values was the resulting value.

Chunking device are two jaws ensuring firm grip of the sample and its axial symmetry with respect to the machine. The machine is equipped with an extensometer measuring the elongation of the simple and a strain-gauge head monitoring the acting force.

The test was finished when the strength dropped by $50 \%$ and the following values were recorded: tensile strength $R_{\mathrm{m}}$, yield point $R_{\mathrm{p} 02}$, drawing quality $A_{80}$ and the exponent of strain hardening $\mathrm{n}$.

\section{TEST RESULTS}

The resulting values obtained from the tests are displayed in the following charts. 


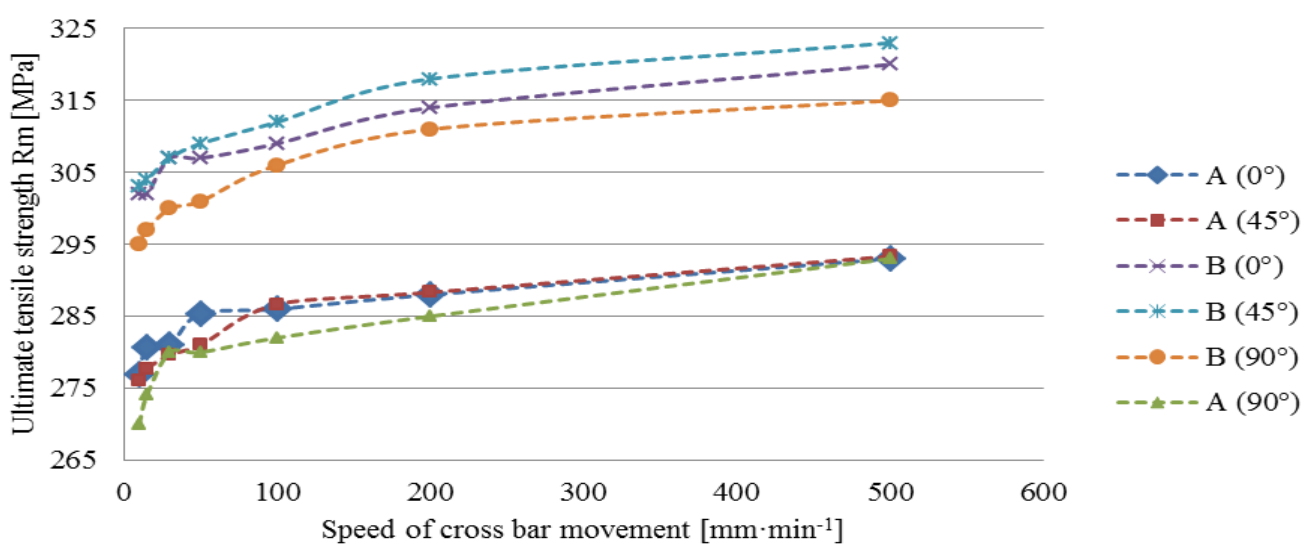

Fig. 2: Effect of the cross bar speed on the ultimate tensile strength $R_{\mathrm{m}}$.

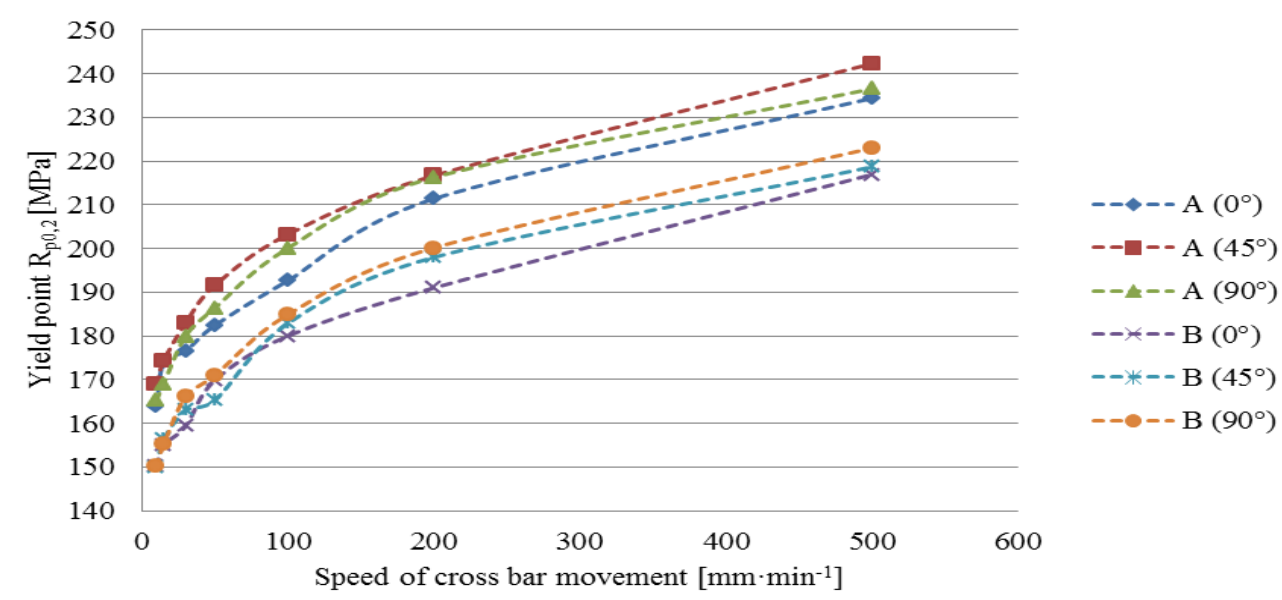

Fig. 3. Effect of the cross bar speed on the yield point $R_{\mathrm{p} 02}$.

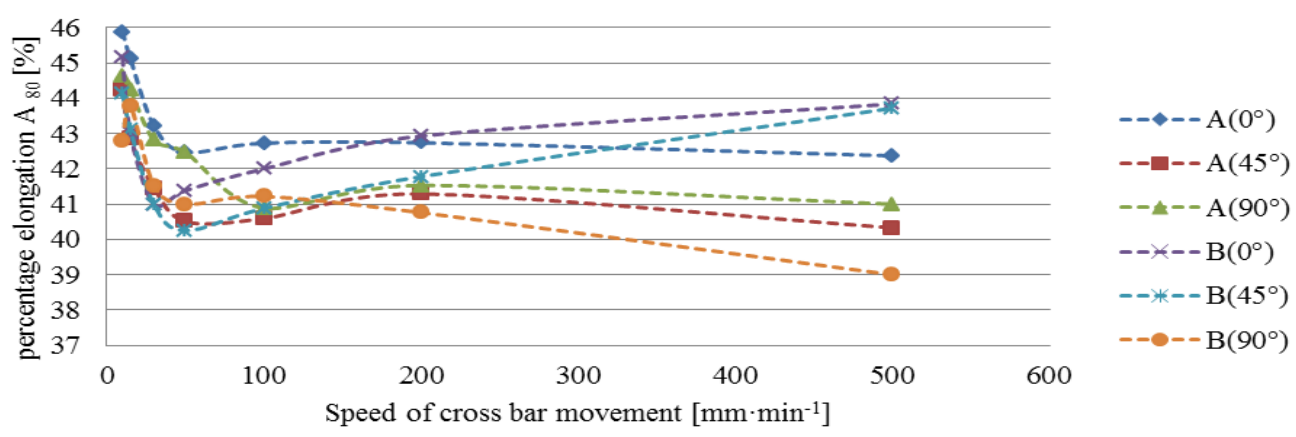

Fig. 4. Effect of the cross bar speed on the drawing quality $A_{80}$. 
The effect of strain rate on the microstructure of samples was observed under the microscope Olympus Lext OLS 3000.

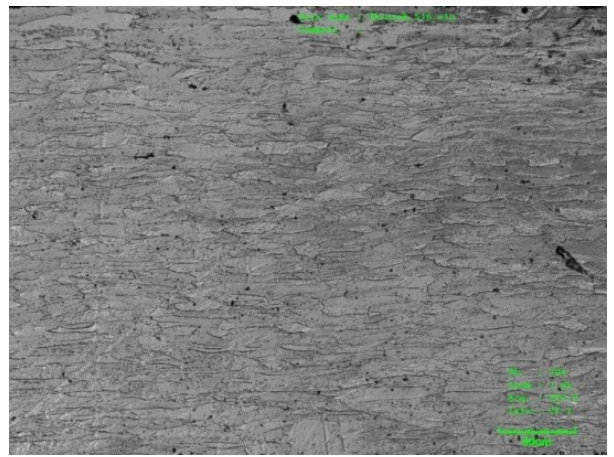

$10 \mathrm{~mm} \cdot \mathrm{min}^{-1}(480 \mathrm{x})$

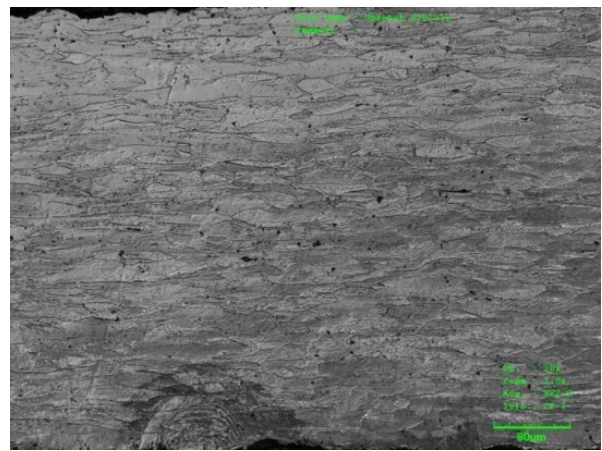

$100 \mathrm{~mm} \cdot \mathrm{min}^{-1}(480 \mathrm{x})$

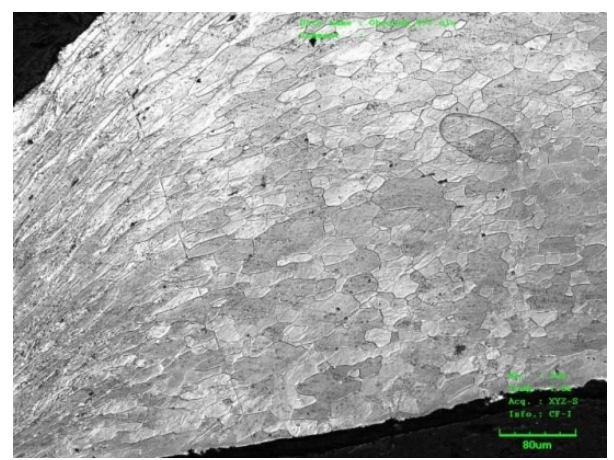

A sample broken by very high kinetic energy (480x)

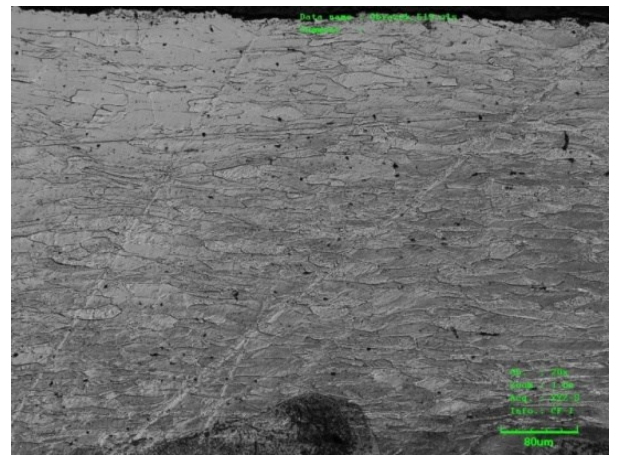

$50 \mathrm{~mm} \cdot \mathrm{min}^{-1}(480 \mathrm{x})$

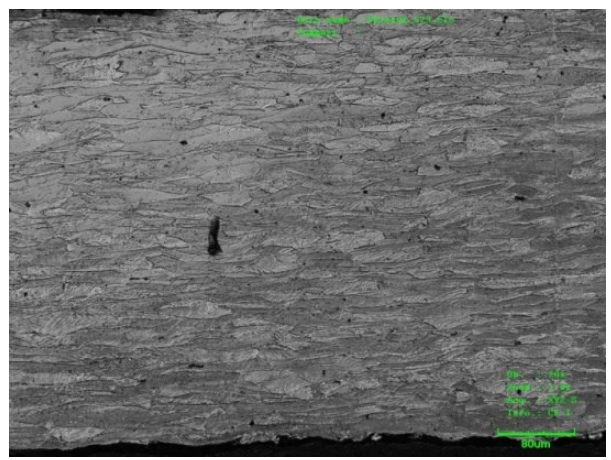

$500 \mathrm{~mm} \cdot \mathrm{min}^{-1}(480 \mathrm{x})$

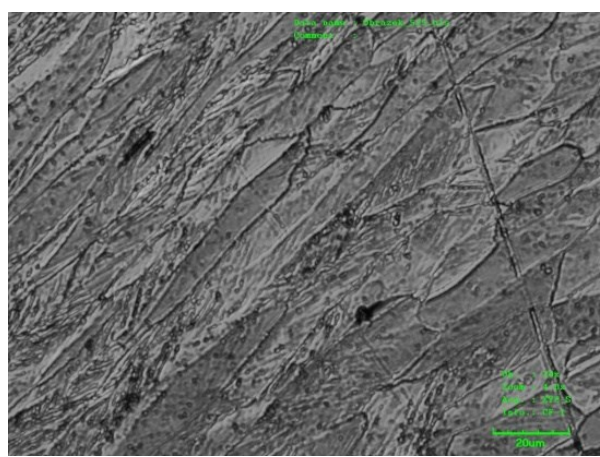

Detail (1200x)

Fig. 6. Effect of the cross bar speed on the microstructure of the DC06 steel.

\section{CONCLUSION}

The completed tests imply that the speed of straining influences material mechanical properties. In general we can say that by increasing the strain rate, in this case by using the cross bar of a tension test machine, the values of mechanical properties change, the yield point and the ultimate tensile strength increase while the drawing quality goes down (Fig. 2, Fig. 3, Fig. 4). The increase in the value of yield point is non-linear and it is nearly of a logarithmic curve, with fast reaching the maximum values at the cross bar speed of about $150 \mathrm{~mm} \cdot \mathrm{min}^{-1}$ and then with slow, almost zero and increase in value. The values of the ultimate tensile strength are approximately linear. The drawing 
quality of material declines until the cross bar speed reaches approx $50-150 \mathrm{~mm} \cdot \mathrm{min}^{-1}$ and then it is constant or slightly rising. The exponent of strain hardening is of falling, mostly linear nature.

The results imply that strain rate has greater influence on the values of yield point than the values of strength. The average differences in the yield points for cross bar $10 \mathrm{~mm} \cdot \mathrm{min}^{-1}$ and $500 \mathrm{~mm} \cdot \mathrm{min}^{-1}$ are approx $70 \mathrm{MPa}$, but the average differences in the ultimate tensile strength amount to approx $25 \mathrm{MPa}$. Thus it is possible to say in general, that at high strain rates the yield point approximates the ultimate tensile strength thus reducing the plasticity of the material and increasing in the risk of brittle failure of the material, which is a negative factor in the area pressing at room temperature.

The microscopic observation of the microstructure of DC06 steels broken at various strain rates imply that material exposed to a higher strain rate, i.e. to the higher speed of cross bar, shows a higher level of deformation. The grains are stretched in the direction of the applied stress with more apparent slip bands; also the area of inhomogeneous plastic deformation is reduced as illustrated in Fig. 6. This fact is especially apparent in samples exposed to a very high strain rate, much higher that the one used for the tension test. The area of inhomogeneous plastic deformation is very close to the point of fracture. As the distance from the point of fracture increases there is a significant drop in the number of distorted grains and grains affected by slip bands.

\section{REFERENCES}

[1] Žídek, M., Metalurgická tvařitelnost ocelí za tepla a za studena, Praha: ALEKO, 1995, 356 s., ISBN 80-85341-45-X

[2] Petruželka, J., Hrubý, J., Strojírenské tváření I. Ostrava: Vysoká škola báňská - Technická univerzita Ostrava, 2002. $152 \mathrm{~s}$.

[3] ČSN EN 10152 (420911) Ocelové ploché výrobky válcované za studena elektrolyticky pozinkované pro tváření za studena. 2004

[4] Boyce, B. L., Dilmore, M. F. The dynamic tensile behavior of tough, ultrahigh strength steels at strain-rates from $0.0002 \mathrm{~s}^{-1}$ to $200 \mathrm{~s}^{-1}$. International Journal of Impact Engineering, 2008, p. $263-271$

[5] Hašek, V., a kol. Lisování. Praha: SNTL, 1971. 542 s.

[6] Petruželka, J., Sonnek, P. Tvařitelnost kovových materiálů. Ostrava: Vysoká škola báňská Technická univerzita Ostrava, 2007.211 s.

[7] ČSN EN ISO 6892-1. Kovové materiály - Zkoušení tahem - Část 1: Zkušební metoda za pokojové teploty 2010 
